\title{
Politikai döntések a gyorsuló időben
}

\author{
BALOGH LÁSZLÓ LEVENTE ${ }^{1}$ - TIM ROJEK ${ }^{2}$ - MANON WESTPHAL ${ }^{3}$
}

\begin{abstract}
ABSZTRAKT
Tanulmányunk célja a döntéselmélet egy olyan problémájának felvázolása, amely a politikaelmélet, a szociológia és a filozófia elméleteinek metszéspontján jelölhető ki. A tanulmányban annak a kérdésfeltevésnek a jelentöségét szeretnénk kiemelni, amely a politikai döntés és a rendelkezésre álló idő viszonyára reflektál. Ennek keretében igyekszünk megtenni azokat a fogalmi megkülönböztetéseket, amelyek a probléma szempontjából leíró és normatív szempontból is nagy jelentôséggel bírnak, ugyanakkor nem lehet célunk megoldások kidolgozása, sokkal inkább a probléma iránti érzékenység kialakítása. Az első részben néhány terminológiai alapvetésünket mutatjuk be, amelyek segítenek a probléma fogalmi körvonalazásában és a döntésről szóló elemzés háttérben meghúzódó feltételezéseink kifejtésében. Ezek után a jelenkori időszociológia néhány téziséből kiindulva vizsgáljuk meg a problémát, majd rávilágítunk a demokráciaelmélet ezzel kapcsolatos néhány sajátos deficitjére. Végül egy alaposabb történeti-elméleti kidolgozás mutatja be, hogy a Német Szövetségi Köztársaság korai időszakában a filozófia, a politika- és jogelmélet területén kiemelkedő jelentőségü Ritter-iskola megfontolásai hogyan teszik lehetővé a felvázolt probléma újragondolását a korábbi fejezetek vonatkozásában.
\end{abstract}

KULCSSZAVAK: döntés, döntési szituáció, döntési folyamat, gyorsulás, demokráciaelmélet, Ritter-iskola

\section{ABSTRACT}

\section{The Acceleration of Political Decision-making}

The detailed description exceeds the scope of this paper, but our aim is to trace a peculiar problem of decision-making theory that can be allocated at the intersection of political theory, sociology and philosophy. What we are trying to do is to emphasize the importance of the relationship between political decision-makingand the timespan available for it. In order to do that, first we make distinctions between some basic concepts that play central rolein the descriptive and normative approach of the issues under review. Second, this paper is not about detailed elaboration of solutions, it does not involve solving the problem, only recognizing that there is a problem. Our aim is therefore to shape problem sensitivity. In the first part we present some terminological

\footnotetext{
${ }^{1}$ Egyetemi docens, Debreceni Egyetem Politikatudományi Tanszék.

${ }^{2}$ WWU-Münster, tudományos munkatárs, SFB 1150.

${ }^{3}$ WWU-Münster, tudományos munkatárs, Institut für Politikwissenschaft.
} 


\title{
KÖZELKÉP - Tanulmányok
}

basic lines in order to outline the conceptual aspect of the problem, and to develop assumptions that underly our decision-making analysis. Next, we approach the problem of decision-making based on some theses of contemporary "time-sociology”(time as sociology's basic concept), and - in relation to that - we point at some specific shortfalls of democracy. Finally, based on a profound historical and theoretical analysis, we show howsome basic considerations of the Ritter-school of the early years of the Federal Republic of Germany make possible for us to reconsider the complex question elaborated above.

KEYWORDS: decision, decision-making situation, decision-making process, acceleration, democratic theory, Ritter-school.

\begin{abstract}
„A modern nyugati világ a maga önértelmezésében hallgatólagosan még mindig azt a felfogást követi, hogy a politika határozza meg a társadalmi és a kulturális fejlődés tempóját." (Rosa 2013: 102)
\end{abstract}

Tanulmányunk célja a döntéselmélet egy olyan problémájának feltérképezése, amely a politikaelmélet, a filozófia valamint a modernitás történelmi és szociológiai megközelítésű elméleteinek metszéspontján jelölhető ki. A következőkben először a kérdésfeltevés jelentőségét szeretnénk kiemelni, és azt többnyire vázlatos megfontolások mentén körvonalazni, illetve igyekszünk megtenni azokat a fogalmi megkülönböztetéseket, amelyek a probléma által felvetett leíró és normatív kérdések szempontjából központi jelentőséggel bírnak. Ugyanakkor már az elején hangsúlyozzuk, hogy nem lehet célunk megoldások kidolgozása, sokkal inkább a probléma iránti érzékenység kialakítása és annak strukturálása.

Céljaink eléréséhez négy lépésben haladunk: az első részben néhány terminológiai alapvetésünket mutatjuk be, amelyek segítenek a probléma fogalmi körvonalazásában és a döntésről szóló elemzés háttérben meghúzódó feltételezéseinek kifejtésében. Ezek után az aktuális szociológia és az újabb kritikai elmélet néhány téziséből kiindulva vizsgáljuk meg a problémát, majd rávilágítunk a demokráciaelmélet néhány sajátos deficitjére, amelyek a korábbi fejezetben vázolt tételek tükrében válnak érthetővé. Végül egy alaposabb történeti-elméleti kidolgozás mutatja be, hogy a Német Szövetségi Köztársaság korai időszakában a filozófia, a politika- és jogelmélet területén kiemelkedő jelentőségű Ritter-iskola ${ }^{4}$ megfontolásai hogyan teszik lehetővé, hogy a felvázolt problémát azokra a kérdésekre élezzük ki, amelyek az első részben kidolgozott koncepciók, a második részben bemutatott modernitásdiagnózis és a harmadik részben vázolt demokráciaelméleti megfontolások tükrében a jelen számára is jelentőséggel bírnak. Befejezésként az eredményeket összesítjük, és rámutatunk arra, hogy a diagnózisból milyen további releváns filozófiai és politikaelméleti kérdések adódnak normatív és deskriptív tekintetben egyaránt.

\footnotetext{
${ }^{4}$ A Ritter-iskolával és hatásával kapcsolatban lásd Schweda (2015) és Hacke (2006).
} 


\section{KÖZELKÉP - Tanulmányok}

\section{Mi a döntés? Koncepcionális megfontolások}

Érdeklődésünk középpontjában azok a következmények állnak, amelyek a demokratikus rendszerek politikai döntéseinek jelenben tapasztalható fejlődéséből és átalakulásából adódnak. Mielőtt még a döntés második részben bemutatandó modernitáselméleti alapjaira rátérnénk, tisztáznunk kell, hogy mi foglalkoztat minket a politikai döntés jelenségével kapcsolatban. A döntés alatt egy olyan folyamatot értünk, amely akkor lép fel, ha egy tárgy tekintetében az a határozott benyomásunk, hogy különböző cselekvési alternatívák lehetségesek. A döntési helyzetek olyan eseményekhez kapcsolódnak, amelyeknél az egyéneknek vagy a csoportoknak egy tárgy vagy tárgytípus vonatkozásában ez a benyomásuk alakul ki, és viszonyulni szeretnének vagy viszonyulniuk kell a cselekvési lehetőségekhez. ${ }^{5}$ Ahhoz, hogy döntési helyzetbe kerüljünk, többé-kevésbé konkrét cselekvési lehetőségeknek kell adódniuk. Mivel ezek nem véletlenszerűek, ezért a szereplőknek kell azokat az alapfeltételezésekhez való viszonyukban megalkotni. Különbséget kell tennünk döntési helyzet, azaz egy olyan esemény, amelynek során az adott lehetőségek közül egyet megvalósításra kiválasztunk, és a döntési folyamat mint cselekvés jellegű lefolyás között, amely a döntési helyzethez vezet. Itt nem kell minden döntési folyamatnak döntésbe torkollnia, a folyamat időlegesen és véglegesen megszakadhat, illetve csendesen el is halhat. Egy döntési helyzet kialakulása szempontjából tehát a döntési folyamat nem elegendő, de mindenképpen szükséges. A különbséget terminológiailag megvilágítja a döntés mint folyamat, és a döntés mint eredmény közötti különbségtétel. A meghozott döntés és annak kivitelezési folyamata terminológiailag úgy is meghatározható, mint a meghozott döntés cselekvésben megnyilvánuló következménye vagy eredménye. ${ }^{6}$

A döntési folyamat megint csak felosztható lépésekre, amelyek során általában a következő részlépések játszhatnak szerepet. 1. A döntési lehetőségek explicit megalkotása, megfogalmazása és legitimációja gyakran a nem elegendőnek tartott alternatíváktól való elhatárolásból születik, mint azoktól a döntési helyzetektől való elhatárolás, amelyek komolyan nem vehetőek számításba. ${ }^{7}$ A különböző lehetőségek kialakításának egyik legfontosabb értelmezési előfeltétele, hogy azok nem azonosak. ${ }^{8}$ Az ilyen eset megkülönböztetendő azoktól az esetektől, amelyek kapcsán az egyik alternatíva a másikat szemantikailag feltételezi, és ez utóbbi azért lehetséges,

${ }^{5}$ A modernitásban abból indulhatunk ki, hogy a résztvevő szereplők cselekvésüket kifejezetten a döntés fogalmába sorolják be. A megelőző történelmi korok számára ez nem volt lehetséges. Ezt kérdést a továbbiakban nem vizsgáljuk, mert ezen a helyen elsősorban a modernitásra koncentrálunk.

${ }^{6}$ Ezen a helyen még meg kell különböztetnünk az empirikus cselekvéskövetkezményeket az analitikus cselekvéskövetkezményektől, amely utóbbira a cselekvés-konzekvencia terminust javasoljuk. Ezek a kiválasztott cselekvési opciók szemantikai implikációi. Ehhez a megkülönböztetéshez lásd: Hartmann (1996: 76-77).

${ }^{7}$ A hétköznapi viták során ebben az esetben „pusztán elméleti” opciókról beszélnénk.

${ }^{8}$ Hiba lenne a következő két kijelentést alternatívaként kezelni szemantikai azonosság alapján: „Minden 25 év alatti férfit csak határozott ideig kell foglalkoztatni.” illetve „Minden férfi munkatársat, aki még nem érte el a negyedszázados kort, csak határozott ideig kell foglalkoztatni." 


\section{KÖZELKÉP - Tanulmányok}

mert az alternatíváknak nem kell szemantikailag kizárnia egymást ahhoz, hogy egymás alternatíváiként érvényesülhessenek. ${ }^{9} 2$. A lehetőségek egymással szembeni mérlegelés $\mathrm{e}^{10}$, a lehetséges cselekvési következmények megfontolása azon célok tükrében történik, amelyeket a döntést hozó személyek követnek. Eközben viták alakulhatnak ki arról, hogy mely célokat kell(ene) követni. 3. A döntési helyzetbe való átmenet akkor következik be, ha a célok megfogalmazása, a lehetőségek felvázolása és mérlegelése lezárult, és már csak egy lehetőséget kell kiválasztanunk. Ez különböző módokon történhet: eldönthető sorsolással, egy retorikailag erős személyiség akaratának érvényesülésével, vagy egy választási rend keretében stb.

A fenti részlépések természetesen a döntés idealizált folyamatát vázolják fel. Nem ritkán azt tapasztaljuk, hogy az egyes részlépések között ide-oda ugrálunk. Lehet olyan benyomásunk, hogy a döntési helyzet már megszületett, de új javaslatok ezt megzavarhatják, és a vitát újraindíthatják. Ha a döntési helyzet egy alternatíva kiválasztásával végződik, akkor azt legitimációs szempontból is be kell biztosítani. Ezért fontos, hogy az elvetett alternatívákat is szem előtt tartsuk például jegyzőkönyv, a résztvevők emlékezete, elbeszélések, sajtóhírek, közlemények formájában, hogy a kiválasztás racionalitását az akkori alternatívák függvényében plauzibilissé tegyük.

Miért fontos egyáltalán az itt felvázolt módon a döntés folyamatával és magával a döntéssel analitikus szempontból foglalkozni?

Számtalan olyan helyzet adódik, amelyben a szereplők egyéni vagy kollektív cselekvése a jövő formálása szempontjából meghatározó. Sok esetben szokás szerint cselekszünk, anélkül hogy a cselekvési lehetőségeknek utánagondolnánk; más esetekben másként cselekszünk, mert bizonyos lehetőségek megvalósítását lehetetlennek tartjuk vagy éppen tiltottak. Sokszor fordul elő, hogy alternatívákat alakítunk ki és kiválasztás révén próbálunk meg a jövőre vonatkozó céljaink tekintetében különbséget tenni. Az ilyen eseteket nevezzük „döntésjellegú cselekvésnek”, amelynek lefolyását ideáltipikus esetben a fent vázolt módon kell elképzelni. A hétköznapokban gyakran beszélünk - többnyire retrospektíve - a cselekedeteinkről mint döntéseink eredményéről, miközben azt nem is előzte meg döntési folyamat. Így a döntés fogalma odáig mehet, hogy a cselekvés minden formáját végül úgy fogjuk fel, mintha azt döntés előzte volna meg. Ha azonban a döntést, mint ahogyan itt javasoltuk, magát is cselekvésként értelmezzük, ${ }^{11}$ akkor az előbbi szemlélet egyrészt

\footnotetext{
${ }^{9}$ Azok a kijelentések, hogy „minden egyetemi alkalmazottat, aki nem professzor, csak határozott ideig kell foglalkoztatni” és „minden férfi egyetemi alkalmazottat, aki nem professzor, csak határozott ideig kell foglalkoztatni", láthatóan különböző alternatívát jelentenek, még ha az első már magában is foglalja a másodikat.

${ }^{10}$ A mérlegelés metaforája nem azt sugallja, hogy a súlyozás folyamatában matematikai módszereket alkalmazunk. Azok talán bizonyos esetekben lehetségesek és kézenfekvőek, de nem jelentenek kényszerűen alkalmazandó eljárást arra vonatkozóan, hogy az opciókat egymással szemben mérlegeljük.

${ }^{11}$ Pontosabban, a magasabb szint cselekvési sémájaként, amelyet az alacsonyabb szint cselekvési sémáinak aktualizálása révén lehet realizálni.
} 


\section{KÖZELKÉP - Tanulmányok}

egy önmagába visszatérő érveléshez vezetne, másrészt azzal is járna, hogy azokat a folyamatokat, amelyek a döntés eredményéhez vezetnek, szem elől tévesztenénk. Ezért aztán egy olyan döntésfogalom kialakítását, illetve döntésjellegű cselekvés fogalmát javasoljuk, amelyben a lehetőségek explicit konstrukciója, azok mérlegelése és kiválasztása is ideáltipikus módon jelenik meg.

Plauzibilisnek tartjuk, hogy legalábbis a kultúrtörténetileg megragadható korokban nem létezett olyan társadalom, amelyben ne lett volna jelen az a funkcionális követelmény, hogy legalább a problémák egy bizonyos részét döntésjellegú cselekvések révén kezeljék. Ezen az általános követelményen túl azonban számtalan történelmi variáns jelenik meg, mind a problémák, amelyeket eldönthetőnek tekintenek, mind a döntések legitimációs alapjai változhatnak. Nem utolsó sorban azok a döntési folyamatok, illetve személyek csoportjai és intézmények, amelyektől döntésjellegű cselekvést várunk el, és akik ezt végrehajtják, kontextustól függőek és történelmileg változnak. Például a nők döntésjellegú cselekvése évszázadokon keresztül a háztartásra korlátozódott, a hivatásválasztás, illetve a politikai és katonai döntések pedig kizárólag a férfiakra tartoztak. A normák, értékek, szabályok és gyakorlatok sokasága jellemzi az egyes társadalmi csoportok - társaságok, egyletek, hivatalok, egyházak, gyülekezetek vagy éppenséggel 19. századi lübecki kereskedőcsaládok döntési kultúráját, ami végső soron a döntésjellegű cselekvéseket valószínűvé vagy valószínűtlenné teszi.

A fentebb javasolt fogalomalkotás lehetővé teszi, hogy a döntési kultúrákat a leírás egy kiválasztott szintjén megragadjuk, és megpróbáljuk annak szerkezetét és változásait magyarázni, vagy egy normatív célkitűzés esetén határait kijelölni. ${ }^{12}$ Ezen a helyen azonban nem kívánunk a különböző döntési kultúrák változásával foglalkozni, ${ }^{13}$ hanem a modern politikára fókuszálunk.

A szociológus Uwe Schimank azt a nézetet képviseli, hogy a modernitásban egy olyan társadalmi formációval van dolgunk, amelyet egyenesen „döntéshozó társadalomként" (Entscheidungsgesellschaft) jellemezhetünk. ${ }^{14}$ Ezen diagnózis szerint a lehetőség szerint döntések révén kezelendő problémák köre folyamatosan nő, amelyek egyben annak a normatív elvárásnak is alá vannak rendelve, hogy racionálisan eldönthetők legyenek. Ez a modern társadalmakat mindenütt kihívás elé állítja. Ha ezt a tézist kísérletképpen elfogadjuk, akkor úgy tűnik, hogy éppen a politika áll azon sajátos tehertétel előtt, hogy döntéseit és intézkedéseit legitimálja, illetve az érintettek számára a nyilvánosság előtt racionálisnak tüntesse fel. Schimank szerint a döntéshozó társadalmat nem csak a döntésjellegű cselekvések számának növeke-

${ }^{12}$ A különböző döntési kultúrák elemzését jelenleg az SFB 1150 „Kulturen des Entscheidens“ (A döntés kultúrái) keretében végzik a münsteri Westfälischen-Wilhelms Universitäten. Lásd: https://www. uni-muenster.de/SFB1150 / (utolsó letöltés: 2017. 08. 07.)

${ }^{13}$ Egy ilyen jellegű célkitűzés szempontjából iránymutató Stollberg-Rilinger (2016).

${ }^{14}$ Vö. Schimank (2005). 


\section{KÖZELKÉP - Tanulmányok}

dése jellemzi, hanem az eldöntendő problémák komplexitása is, mivel a premodern korhoz képest az empirikus tudás rendkívüli mértékben megnőtt. Ezeket a tehertételeket a következőképpen foglalja össze:

„A magasfokú komplexitás körülményei között születő racionális döntés elvárásával először azok terhelik meg a cselekvőt, akik megfigyelhetik őt és adott esetben szankcionálhatják is. Ezentúl viszont a cselekvő saját magát is terheli ezzel az elvárással. A nevelés és a szocializáció más formái révén maga a cselekvő is nagymértékben internalizálja azt az elvárást, hogy racionálisan kell döntenie." (Schimank 2005: 11)

A következőkben a racionális döntések kihívásának hatásait, illetve ezek vonatkozásában különösképpen a társadalmi folyamatok felgyorsulásának következményeit szeretnénk megvizsgálni. Ennek kapcsán nem annyira a politikai döntések eredményei érdekelnek minket, hanem a döntési folyamat maga, és annak a változó normák, a problémák érzékelése és a legitimációs követelmények fényében bekövetkező változásai. A sajátos döntési folyamatok kultúratudományi nézőpontjai és a politikai folyamatok, mint döntési folyamatok legitimációs céljai szempontjából releváns inszcenálásai lehetővé teszik a demokratikus döntési folyamatok komplexitásának újfajta normatív és leíró perspektívájának vizsgálatát.

\section{A modernitás akceleratív feltételei}

Hartmut Rosa a nyugati modernitásról szóló szociológiai elméletében a klasszikus modernitástényezők sorát, mint például kapitalizmus, iparosítás, nemzetállamok genezise, egy további, mind ez idáig figyelmen kívül hagyott faktorral, a gyorsulás jelenségével egészítette ki. ${ }^{15}$ Rosa szerint szükség van a társadalmi gyorsulás szisztematikus elméletére és meggyőző fogalmára. A modernitás egy olyan kor, amelyben a várakozás és a gyorsuló folyamatok célra irányuló elindítása a modern társadalmak céljai közé tartoznak. Rosa a társadalmi gyorsulás jelenségét következményei tükrében ambivalensen szemléli. Mindez a komplex tömegtársadalmak számára olyan hasznokkal jár, mint a rövidebb utazási idő vagy azon készülékek cseréje, amelyek gyorsabb és jobb kommunikációt tesznek lehetővé. A másik oldalon azonban megjelenik a természet fokozódó kizsákmányolása, valamint a társadalom különböző részterületeinek gyorsulásból adódó komplex viszonyai, illetve ezek deszinkronizációja. ${ }^{16} \mathrm{~A}$ kiegyensúlyozottság ilyenfajta hiánya a modern társadalom számos problémájáért - legalábbis részben - felelőssé tehető. Mielőtt ezt a problémát tár-

\footnotetext{
${ }^{15}$ Vö. Rosa (2005), illetve újabb normatív hangsúlyokkal bővítve Rosa (2013).

${ }^{16}$ Vö. Rosa (2013: 11. fejezet).
} 


\section{KÖZELKÉP - Tanulmányok}

gyaljuk, röviden felvázoljuk a társadalmi gyorsulás fogalmát. Rosa szerint a társadalmi gyorsulás három kategóriáját különböztethetjük meg, jóllehet ezek egymással empirikusan sokféleképpen összefüggenek.

1. A legnyilvánvalóbb eset a technikai gyorsulásé. Itt elsősorban a kommunikációs folyamatok sebességének növekedésével, a szállítási és utazási, illetve előállítási folyamatok gyorsulásával van dolgunk. Tágabb értelemben a technikához tartozik a szervezési folyamatok hatékonyságának növelése is, amely például a New Public Management kifejezett szándékaihoz tartozik. ${ }^{17}$ Ennek céljai abban állnak, hogy a hatékonyságot a gyorsaság révén növeljék, például az ügyfelek kéréseinek feldolgozásában, vagy a hivatali kommunikációs folyamatokban és a tervezésben.

2. Második kategóriaként a társadalmi változások gyorsulása jelölhető meg. Rosa a gyorsulás ezen dimenziójának leírásakor Reinhart Koselleck és Hermann Lübbe megfontolásaihoz kapcsolódik, amit Lübbe a jelenzsugorodás fogalmával igen találóan írt le. ${ }^{18}$ Ezalatt annak az időtartamnak azt a szisztematikus rövidülését értjük, amelyen belül az ember az életvilágban és a tudományban elsajátított tudásra és készségekre hagyatkozhat, mind propoziocionális, mind praktikus értelemben, anélkül, hogy állandóan gondokba és nehézségekbe ütközne a hétköznapokban. Rosa Koselleck nyomán feltételezi, hogy a tapasztalati tér és a várakozási horizont, ${ }^{19}$ amelyeken belül a már megszerzett tudásra hagyatkozhatunk, a kései modernitásban olyan mértékben szűkültek össze, hogy ezek a tudástartalmak már csak egy generáción belül érvényesülnek. ${ }^{20}$ Tudásunk nagy része már egy generáción belül elavul, ami az érintettektől folyamatos tanulást követel, az embernek tehát folyamatosan újabb technológiákra és üzemmódokra kell átállni. Miközben a fiatalon az oktatásban megszerzett tudás érvényének elvesztése a premodern korban több generáción keresztül ment végbe, a modern korban ez generációról generációra zajlik, illetve azon belül is fokozódik. Ha ez a feltételezés helyes, akkor a társadalmi változások sebességének gyorsulásával van dolgunk a világról alkotott elméleti és gyakorlati tudásunkat illetően is.

3. Rosa harmadik tényezőként az élettempó gyorsulását emeli ki, ami úgy definiálható, mint a cselekvési és élményepizódok számának egy időegységen belüli növekedése, és mint ilyen egy vágy vagy érzelmi igény következménye, hogy több dolgot csináljunk kevesebb idő alatt.

\footnotetext{
${ }^{17}$ A New Public Management céljaihoz és hatásaihoz kritikai megközelítésben l. Crouch $(2011 ; 2015)$.

${ }^{18}$ Vö. Lübbe (1998).

${ }^{19}$ Vö. Koselleck (2003).

${ }^{20}$ Vö. Rosa (2013: 24. fejezet).
} 


\section{KÖZELKÉP - Tanulmányok}

Különösképpen erre a kategóriára vonatkozik Rosa azon diagnózisa, hogy a modernitásban az az általánosnak tekinthető benyomás terjedt el, hogy az embereknek a technikai folyamatok és a társadalmi változások gyorsulása ellenére nem több, hanem egyre kevesebb ideje van. Ez vezeti Rosa-t ahhoz a kultúrkritikai tézishez, amely szerint a modernitásban a feladatok növekedési rátája a feladatfeldolgozás gyorsulásának növekedését folyamatosan felülmúlja. Röviden, a növekedési mutatók felülmúlják a gyorsulási mutatókat. Ezzel magyarázhatjuk azt a paradox hatást, hogy sok minden felgyorsul, de az időkeret egyre szúkebbnek tűnik. Rosa azt a normatív kérdést teszi fel, hogy ennek minden körülmények között így kell-e lennie, és hogy a társadalmi gyorsulás negatív következményei korlátozhatóak, illetve kivédhetők-e? ${ }^{21}$

Mindenekelőtt azonban Rosa megfigyeléseinél maradunk és a következőkben a modern demokratikus politika kérdéskörére koncentrálunk. Rosa szerint a társadalom sokszínű gyorsulási folyamatai lassító mellékkövetkezményekkel járnak együtt. Ezek közé tartozik a forgalom lassulása a nagyvárosokban. ${ }^{22} \mathrm{~A}$ gyorsulási folyamatok egyik sajátos mellékkövetkezménye különösen fontos számunkra: a társadalom azon részterületeinek felgyorsulása, amelyek más területekkel érintkeznek, a „deszinkronizálódás patológiájához" vezethet. Különböző társadalmi szférák különbözőképpen képesek gyorsulásra. Például az iskolai oktatást hatékonyabbá lehet tenni, de a gyermeknevelés időtartamát és tempóját csak korlátozott mértékben lehet növelni. A demokratikus politika döntéshozatali folyamatainak Rosa egy sajátos „hanyagságot” tulajdonít, amelyek a társadalmi együttműködés rendszerszerű jellegéből adódnak. Mivel a technika és a gazdaság területei sokkal hajlamosabbak a gyorsulásra, ezért a politika állítólagos „hanyagsága” tehet arról, hogy nem képes többé a technika és a gazdaság által kiváltott társadalmi változásokra adekvát módon reagálni. A szinkronizációs folyamatokra általánosságban jellemző:

„Mihelyt két folyamat összekapcsolódik, azaz szinkronizálódik, a gyorsabb elem a másikat sürgetni kezdi (...) amíg a lassabb elem fel nem gyorsul ugyanannyira, addig azt bosszantó akadálynak vagy a működést gátló tényezőnek tekintjük." (Rosa 2013: 99)

A modern demokráciát így az fenyegeti, hogy őt magát is a múködést gátló tényezőnek fogják tekinteni. A demokráciát ezért gyakran nem látják már elég hatékonynak ahhoz, hogy a modernitás kihívásaira választ tudjon adni. Rosa diagnózisa megnyitja annak lehetőségét, hogy azzal az olyan jelenségeket megmagyarázzuk,

${ }^{21}$ Itt Rosa olyan jelenségekre gondol, mint a burnout, depresszió vagy erős stressz (Vö. Rosa 2013: 9. fejezet).

${ }^{22}$ Ezek a fellépő lassító tényezők azonban, mint ahogyan a közlekedési dugó példája ezt evidenssé teszi, nem vezetnek a feszültség és a stressz csökkenéséhez az élettempóban. 


\section{KÖZELKÉP - Tanulmányok}

mint a „politika romlása” vagy az autoriter politikai rendszerek sikere, amelyeknek az új problémákra való gyors és dinamikus reagálást tulajdonítanak. Az ebben rejlő problémákat a következőkben foglalja össze:

„Ha alapvetően demokratikus társadalmakban akarunk élni, akkor a politikának meg kell határoznia azokat a fejlődési kereteket és irányokat, amelyekben a tudomány, a gazdaság és a technika múködnek. Mindez a politika időben való sajátos meghatározását feltételezi, azaz feltételezzük, hogy a (demokratikus) politikai döntéshozatal szinkronban van vagy legalábbis szinkronizálható a szocioökonómiai és szociokulturális fejlődéssel. (...) A demokrácia esetében azonban egy időigényes folyamatról van szó. Egyszerűen időbe telik a nyilvánosságot megszervezni, a releváns társadalmi csoportokat azonosítani, érveket megfogalmazni és mérlegelni, egységre törekedni és megfontolt döntéseket hozni. Ezen túl a jogállami, azaz nem totalitárius társadalmakban, ezeknek a döntéseknek a végrehajtása is időigényes." (Rosa 2013: 102)

A probléma részben azáltal oldható fel, hogy megpróbáljuk kimutatni, az autoriter államberendezkedések, például a korrupcióra való hajlamuk miatt, egyáltalán nem olyan hatékonyak, mint ahogyan azt először feltételeznénk. Arra a kérdésre azonban nem kapunk választ, hogy a növekvő technikai és gazdasági gyorsulás körülményei között lehetséges-e a politikai keretek meghatározása és irányítása, és ha igen, akkor hogyan. Rosa szerint éppen azon demokráciák döntési folyamatai és döntési kultúrái helyeződnek nyomás alá, amelyek a társadalmi gyorsulás miatt legitimációs és cselekvési kényszernek vannak kitéve. A továbbiakban azzal érvelünk, hogy a demokráciaelméletek deszinkronizációs problémáinak elismerése szisztematikus változtatásokat igényel, és a negyedik részben megmutatjuk, hogy az ún. Ritter-iskola megfontolásai hogyan járulhatnak hozzá a demokráciaelméletek megfelelő újragondolásához.

\section{Politikai döntés a demokráciában és a demokráciaelméletben}

A politikai döntések különlegessége abban áll, hogy azok mindig (a) kollektív döntések $^{23}$ és (b) alternatív cselekvési lehetőségek konfliktusai nyomán születnek. Ha va-

${ }^{23}$ A „kollektív” ebben az esetben kétféle dolgot jelent. Egyrészt a kollektív mint döntéshozó jelenik meg. Nem egyetlen egy, hanem több személy a döntési folyamat szereplője. Másrészt a kollektív a döntések érvényességi igényére vonatkozik. A politikai döntéseknél a kollektív révén - vagy a kollektív számára - kötelező döntésekről van szó. Még ha a politikai közösség nem is minden része érintett egyformán - gondoljunk csak bizonyos kisebbségi jogokat érintő politikai döntésekre - a döntés eredményét mindenkinek el kell fogadnia. 


\section{KÖZELKÉP - Tanulmányok}

laki, mint Rosa is, a társadalmat Luhmannhoz hasonlóan koordinációs összefüggések funkcionális differenciálódásának eredményeként értelmezi, akkor a politika olyan részterületként definiálható, amelynek meghatározó funkciója, hogy kötelező érvényű döntéseket generáljon a társadalmi konfliktusok megoldására.

„Ezen funkció, a kollektíve kötelező döntések lehetőségének garanciájaként és igény szerinti aktualizálásaként, a politika megfigyelését és megítélését elsősorban a konfliktusok kezelésére irányítja, amelyeket tematizál, és a megítélés kritériuma abban áll, hogy döntenek-e, és ha igen, hogyan." (Luhmann 2000: 134)

Ezek szerint a politikai döntéshozatal különleges körülmények között történik. Miközben a cselekvési alternatívák mérlegelése, ahogyan azt az első részben a döntési folyamat szükséges részeként leírtuk, az egyéni döntések esetében - például a párkapcsolatokkal vagy a munkavállalással kapcsolatos fontos döntések az életben - a szubjektív preferenciák és értékrendek mindenkori racionalitáskritériumai alapján történik ${ }^{24}$, az kevésbé világos, hogy melyek a racionális megfontolások kritériumai a politikai döntési folyamatokban. Ha egy politikai döntéshozatal egyáltalán szükséges, mert konfliktusok vannak egy politikailag szabályozandó tárgy dolgában, akkor a nézetek és szempontok pluralitása figyelhető meg arra vonatkozóan, hogy mi lenne a mérlegelési folyamat helyes vagy legjobb eredménye. Azaz a döntési folyamatnak konfliktusszabályozó folyamatnak kell lennie - a jó politikai döntések kritériumai válaszokat foglalnak magukban azt illetően, hogy hogyan kell kezelni a véleménykülönbségeket egy politikai közösség tagjai között. Egy normatív demokrácia-, ill. politikaelméletben legalábbis ennek kell érvényesülnie. Leíró szempontból nézve azonban fontos megállapítani, hogy mely forrásokhoz nyúlnak vissza a politikai döntéshozók, hogy azokat „racionálisnak” tekintsék. Ez utóbbi eljárással még nem mondtunk ítéletet arról, hogy a racionalitáskritériumok érvényre tarthatnak-e számot, hiszen ebben az esetben egy tiszta eredet-diskurzusban mozgunk. ${ }^{25}$

Ideáltipikusan három politikai döntésmódot különböztethetünk meg: a konfliktusokat el lehet dönteni a, hierarchikusan, b, többségi elv és c, konszenzuskeresés alapján. (Vö. Eberlein és Grande 2014: 152) ${ }^{26}$ Az első esetben a hatalommal rendel-

${ }^{24}$ A mérlegelés ebben az esetben nem egy rational-choice modellhez kapcsolódik, hanem egy hétköznapi megfontolási és döntési folyamathoz, amely nem igényel elméleti megközelítést.

${ }^{25} \mathrm{Az}$ eredet és az érvényesség megkülönböztetésére l. Wille 2012: 28-61. Döntéselméleti megfontolásaink, amelyeket ezen a helyen a demokráciaelméletre szúkítettünk, alkalmasak mind a normatív (az érvényességre vonatkozó), mind a deskriptív (az eredet kérdését érintő) vizsgálódásokra.

${ }^{26}$ Ezért a konszenzust általában nem tekinthetjük olyan döntési módnak, amelyet a konfliktusra és nézetkülönbségre adott válasznak gondolunk. Az elérendő célt azonban - legalábbis a demokrácia keretei között - abban az értelemben konszenzusosnak tekinthetjük, hogy a konfliktus megoldásának arra kell 


\section{KÖZELKÉP - Tanulmányok}

kező szerv dönt, a második esetben a többség, a harmadikban pedig - ideális esetben - minden résztvevő.

A normatív demokráciaelméletnek fenntartásai vannak az első lehetőséggel kapcsolatban, mégpedig azon alapelvből kiindulva, hogy a polgároknak egy demokratikus rendben osztoznia kell a döntéshozatalban. Nem a már fennálló hatalmi viszonyoknak kellene arra választ adniuk, hogy mit kezdjünk a politikai véleménykülönbségekkel, hanem magának a politikai folyamatnak, mint kollektív koordinációs folyamatnak, amely elvileg minden polgár számára nyitva áll. A többségi elv és a konszenzuskeresés megfelelnek ennek az elvnek. A többségi döntés esetén minden polgárnak, illetve a konfliktusban résztvevő minden félnek lehetősége van arra, hogy meggyőzés és szövetségesi politika révén politikai céljaik érdekében koalíciót hozzanak létre, illetve - döntéselméletileg szólva - az általuk előnyben részesített döntési alternatíva létrehozásának és választásának érvényt szerezzenek. A többségi elv magában hordozza, hogy az alulmaradó kisebbségnek a többség döntése előtt meg kell hajolnia. Ahhoz, hogy elejét vegye a többség zsarnokságának, a demokrácia rá van utalva, hogy a többség magát önként korlátozza és a kisebbség igényeit is figyelembe vegye, illetve hogy a hatalomgyakorlásnak bizonyos alkotmányos korlátokat szabjon. (Vö. Rüb 2002: 100) ${ }^{27}$ De még ha a megfelelő mechanizmusok rendelkezésre állnak és elfogadásra találnak is, a konszenzuskeresésnek van egy szembeötlő előnye a többségi döntéssel szemben: ez gondoskodhat arról, hogy a fennálló konfliktushelyzet átalakuljon és egy olyan cselekvési opciót válasszanak ki, amely minden résztvevő számára 'racionálisnak' vagy legalábbis eléggé elfogadhatónak tűnik. Ezzel nem csak a döntési folyamat válik inkluzívvá, ami egyébként a többségi elv érvényesülése esetén is fennáll, hanem a döntés eredménye is. A konszenzuskeresés tehát kiegészíti a politikai döntések procedurális inkluzivitását egy szubsztanciális inkluzivitással.

Meglehetősen vonzó elképzelésnek tűnik, hogy a demokráciát leginkább egy olyan folyamatként értelmezzük, amelynek során minden résztvevő ugyanolyan eséllyel érvel ésszerűen a közjó kérdéseiről, miközben az a cél, hogy a lehető legszélesebb körű egyetértés jöjjön létre ahelyett, hogy a többségi döntéssel gyors eredményre jutnánk és a kisebbséget vesztessé tennénk (Nolte 2012). Ez az eszme a demokráciaelmélet irányainak normatív programjává vált, amely minden másnál inkább meghatározza a jelenlegi diskurzust, nevezetesen a deliberatív demokráciaelméletet. A deliberatív elméletek képviselői a politikai döntések során a proce-

épülnie, hogy a politikai döntési folyamatban az alulmaradt fél is elfogadja az eredményt. Egy háttérben meglevő konszenzusnak, amely a demokratikus folyamatnak megfelelő döntési eredményt legitimnek nyilvánítja, rendelkeznie kell egy „prediszkurzív beleegyezéssel”.

${ }^{27}$ Amelyeknek aztán megint csak mint a politika számára kötelezően elfogadott „játékszabályokként" kell érvényesülniük. 


\section{KÖZELKÉP - Tanulmányok}

durális és szubsztanciális inkluzivitás korlátozása mellett érvelnek, amikor abból indulnak ki, hogy egy diszkurzív eljárás során a konfliktusban résztvevők minden releváns érv racionális és általánosítható minőségét felülvizsgálhatják, és ezúton közelíthetnek a vita tárgyát képező probléma elfogadható megoldásához. A deliberatív demokráciaelméletekben ez a gondolat nem leíró - egyértelmű, hogy a valóságban a döntési folyamatok másként alakulnak - hanem egy kifejezetten előíró jellegű tézis. A döntéseknek deliberatív folyamatok eredményeként kell megszületni, amelyekben minden érintett közvetlenül vagy képviselőin keresztül részt vehet, mert csak így lehetségesek az ideálisan legitimált döntések (vö. Besson és Marti 2006: XV).

Sok mindent mondhatnánk még a deliberatív demokrácia eszméjéről, de ezen a helyen a mellette és ellene szóló érveket felvonultató vitát nem tudjuk eldönteni. Ezen a helyen arról van szó, hogy a deliberatív demokráciaelméletnek és az általa alapvetően meghatározott demokráciaelméleti diskurzusnak megvannak a gyenge pontjai.

Ha az a fentebb már felvázolt modernitásdiagnózis helyes, hogy a társadalom egyes részterületeit a gyorsulás jellemzi, aminek következtében a demokratikus politikát egyfajta múködési akadálynak tekintik, akkor úgy tűnik, hogy a deliberatív demokráciaelmélet egy olyan legitimációs ideált mutat fel, amely a politika és a társadalmi részterületek közötti deszinkronizálódást még inkább előmozdítja: az inkluzív deliberatív érvelési folyamatok meglehetősen időigényesek, és emiatt várhatóan lelassítják a politika döntési eljárásait. Az érvek kifejtése és a meggyőzés sok időbe telik. Úgy tűnik, hogy ezért a demokráciaelmélet az elmúlt évtizedekben az időszempont tekintetében nem járt jó nyomon. Ha olyan választ akar adni, amely a társadalmi gyorsulást elméleti szempontból nem hagyja figyelmen kívül, akkor a politikai döntési folyamatokat másként kell leírnia és másként kell legitimációját biztosítani, mint ahogyan azt a deliberatív demokrácia konszenzusideálja feltételezi. ${ }^{28}$

A következőkben megmutatjuk, hogy az úgynevezett Ritter-iskola körül, egy az itt felvázolt vitákat történelmileg messze megelőző filozófiai, a politika- és jogelméleti gondolkodói irányzat körében, hogyan fogalmazódtak meg a felvázolt problémakör releváns kérdései. Ehhez először is pontosítjuk, hogy szerintünk miben is áll a demokráciaelmélettel szembeni döntéselméleti kihívás lényege. 1. Az általános társadalmi gyorsulás a politikát, mint társadalmi részterületet, amelynek funkciója a társadalmi konfliktusok megoldására kötelező érvényű döntések meghozatala, döntéshozatali nyomás alá helyezi. ${ }^{29} \mathrm{~A}$ döntési folyamatoknak, amelyek egy konflik-

${ }^{28}$ Ez az érvelés és az „időpolitika” programjának ezen megközelítése megtalálható Müller-Salo és Westphal tanulmányában (2018).

${ }^{29}$ A sürgető döntési helyzet előállásának legalább két feltétele van: 1. Egy döntés nem meghozatala vagy halogatása olyan hatásokat eredményez, amelyek a döntés értelmére kihatnak. (Aki túl későn dönt arról, hogy tegyen valamit a klímaváltozás ellen, annak már nem szükséges arról döntenie, mert a hatásai nem fordíthatók vissza minden további nélkül. Egy erről szóló döntés elvesztené értelmét.) 2. Az érintetteknek úgy kell tekinteni a döntési helyzetre, mint egy időben korlátozott szituációra, tehát így vagy úgy, 


\section{KÖZELKÉP - Tanulmányok}

tushelyzetből indulnak ki, és a konfliktuskezelési folyamaton keresztül döntési eredményeket kell felmutatniuk, gyorsan vagy gyorsabban kell történniük ahhoz, hogy a felgyorsult társadalmi folyamatokkal tudják tartani a lépést. 2. Az a mai demokráciaelméletekben uralkodó eszme, hogy a legitim politikai döntéseknek minden döntésben érintett számára racionálisnak kell lennie, szükségszerűen részletes és időigényes tanácsadási és érvelési folyamatok követelésébe torkollik, amelyek éppenséggel nem a politikai döntési folyamatok gyorsulását, hanem lassulását vonják maguk után. 3. A politikai döntésre irányuló reflexióknak ezért más legitimációs alapot kell keresnie, mivel a konszenzuskeresés és az arra tett kísérlet, hogy a vita tárgyát képező konfliktust olyan eredménnyel zárják le, ami minden érintettnek egyformán elfogadható, a kordiagnózis szempontjából anakronisztikusnak tűnik. Más szóval, a legitim politikai döntéseknek szüksége van egy olyan kritériumra, amely nem redukálható az általános elfogadhatóság minőségével azonosított racionalitásra, hanem elfogadhatóvá teszi azokat a döntéseket is, amelyek szűkös források és idő szűkében születnek, és nem lesznek azonnal irracionálisak a normatív elfogadhatatlanság értelmében.

\section{A döntések eredményei és az idő szűkében hozott döntések - a Ritter-iskola}

A Ritter-iskola legismertebb képviselői, Odo Marquard és mindenek előtt Hermann Lübbe már kezdettől fogva felhívták a figyelmet a politikai döntések körülményei és az életvilág folyamataiban tapasztalható gyorsulás összefüggéseire. A döntés és az idő viszonya egy meglehetősen paradox helyzetet teremt, amelyet egyrészt az idő hiánya, másrészt a döntés kényszere jellemez. A helyzetet a következőképpen tudjuk leírni: az életvilág folyamatai egyre gyorsabban zajlanak, ami tapasztalatvesztéssel jár együtt; ugyanakkor az idő szorításában újra és újra, egyre több elodázhatatlan döntést kell hoznunk.

Ahhoz, hogy a helyzetet pontosan megérthessük, abból kell kiindulnunk, hogy a modernitás viszonyai között egyre kevesebb idő áll rendelkezésünkre, amit Hermann Lübbe igen találóan „jelenzsugorodásnak” nevez (Lübbe 2003). A jelenzsugorodás a modern időtapasztalat egy sajátos jelensége, ami annyit tesz, hogy: „egy dinamikus civilizációban az egységnyi idő alatt bekövetkező innovációk számának növekedésével összefüggésben csökken azon évek száma, amelyekre visszatekinteni annyit tesz, hogy az élet fontos szempontjaiból elöregedett világra tekintünk vissza, amelyben a

tudatában kell lenniük annak, hogy a döntést egy bizonyos idő alatt kell meghozniuk, ha még meg akarják őrizni a folyamat feletti befolyásukat. A döntési folyamatok gyakran kezdődnek az események iránt való érzékennyé tétellel, amelyek egy bizonyos időn belüli döntést követelnek tőlünk. 


\section{KÖZELKÉP - Tanulmányok}

jelenben ismert életvilágunk struktúráit már nem vagyunk képesek újra felismerni, és amely olyannyira idegen, sőt érthetetlen múlttá vált. (...) A jelenzsugorodás ezen túlmenően azt jelenti az idegenné vált múlt kronológiai távolságának rövidülése tekintetében, hogy azon évek száma is rohamosan csökken, amelyekre előre tekinteni annyit tesz, hogy egy jövőbe nézünk, amelyben olyan életkörülményekkel kell számolnunk, amelyek lényegi szempontokból többé már nem hasonlítanak a mai életkörülményeinkhez." (Lübbe 2000: 11)

A jelen időben való lerövidült tartózkodás tehát azt jelenti, hogy egyre kevesebb állandósággal, és egyre több változással kell számolnunk az életben. Ez a folyamat nem teljesen új, mert már a régi korokban is voltak innovációk következtében bekövetkező változások, ami azonban új, az a változások mennyisége és sebessége egyetlen emberi élet idején belül. A jelenzsugorodás mára egy természetes folyamattá vált, amely nem állítható meg és tartóztatható fel, ezért állandó kihívást jelent az emberi alkalmazkodóképesség számára.

A kihívások kiéleződnek, mert állandóan tapasztalatvesztéssel járnak együtt. Az elvesztett tapasztalatok közé soroljuk azokat a tapasztalatokat, amelyek „fizikai és társas létünk civilizációs feltételeinek megértésében segítenek bennünket (...) A tapasztalat által közvetített világról szóló tudás társadalmi hatóereje zsugorodik. Ez a civilizációs fejlődésünk két fő strukturális jellemzőjének az egyértelmű következménye, vagyis a komplexitás növekedéséé, mint funkcionális differenciálódásé egyrészt, és az evolúció sebességének növekedéséé másrészt (Lübbe 1979).

Odo Marquard szerint a tapasztalatvesztés abban áll, hogy „,a modern világban az élettapasztalatok tartóssága csökken, romlandóságuk pedig nő, mert ennek a világnak a viszonyai mindig gyorsabban változnak, mint ahogyan elsajátítják őket. Az élettapasztalat elöregedési sebessége nő, mert a modern világ változási sebessége is nő." (Marquard 2004: 43)

A folyamatnak az a következménye, hogy egyre több információ áll rendelkezésre, amelyek szükségszerűen döntés elé állítanak minket, ha csak nem akarjuk ezen információk - mint például a klímaváltozás vagy a természeti erőforrások végessége - tartalmát ignorálni. ${ }^{30} \mathrm{~A}$ társadalmi valóság egy egyre komplexebb struktúrát mutat fel és közvetlen tapasztalatok révén már nem lehet megérteni. Az információk gyarapodása azonban nem vezet szükségszerűen jobb tájékozódáshoz, hanem sokkal inkább rá vagyunk utalva mások tapasztalataira, az iskolák és egyetemek által közvetített intézményes és a média által inszcenált tudásra. A tapasztalatok elvesztése szorosan összefügg az általános gyorsulással, amely az élet legkülönbözőbb területeire terjed ki, és a tájékozódó képesség elvesztéséhez valamint a tehetetlenség érzéséhez vezethet, miközben a tevékenységi körök állandóan bővülnek és a cselek-

${ }^{30}$ Ez többek között a modern társadalmakat jellemző „eltudományosításnak” köszönhető. (Vö. Raphael 1996.) 


\section{KÖZELKÉP - Tanulmányok}

vési lehetőségek jelentős mértékben gyarapodnak. Egy ilyen folyamat során az „egyszerű életbe" visszavezető rousseau-i ideál sem nem elképzelhető, sem nem kívánatos. Az életvilág eme jellegzetessége a modernitás alapvonása, amelyet nem lehet ugyan megváltoztatni, de legalább kompenzálható valamelyest. A veszteségek oka a felgyorsult és feltarthatatlan haladás, ezért meg kell kísérelni az általános gyorsulás politikai következményeinek kérdésére választ adni, amely a modernitással és gyorsulásával számot vet, miközben nem száll vele szembe valamilyen modernitásellenes elképzelés nevében.

Minél bonyolultabbak és átláthatatlanabbak a politikai modernitás konstellációi, annál erősebb a döntéshozókra nehezedő nyomás. A döntés kényszere gyakran a hagyományok érvényének gyengeségéből adódik, ami megint csak a tapasztalatvesztésből adódik. ${ }^{31}$ Ebben az értelemben a döntésnek egy nagyon általános, de a modernitás körülményei között nagyon különleges jelentősége van. Hermann Lübbe szerint a döntési helyzetek azok, „amelyek egyszerre nem lehetségesek, és amelyek közül csak az egyik érvényesülhet (...) A döntés az az aktus, amelynek során azokban az esetekben, amikor az egymást kizáró lehetőségeket nem lehet megkerülni, az egyiket kizárjuk, hogy a másik megvalósulhasson. A döntés a szükségszerúség kényszere alatt áll, jóllehet meghozatalának a szabadság előfeltétele." (Lübbe 1965: 12)

Ebben a definícióban nyoma sincs a Carl Schmitt-féle decizionizmusnak, amely bizonyos tekintetben hatott a Ritter-iskola tagjainak döntésről alkotott elképzeléseire. ${ }^{32}$ Ebben a definícióban szó sem esik a szuverénről és a kivételes állapotról. A politikai döntés ebben az értelemben pusztán a politika egyik fontos funkciója a többi között, amelynek az a célja, hogy a mindenkori politikai rend fenntartsa magát. „A döntési kényszer végső soron az önfenntartás egyik funkciója." (Lübbe 1965: 13) Így a döntésnek semmilyen különleges és rendkívüli jellege nincs. A döntést megfosztja drámaiságától és a politikai normalitás körébe utalja. Lübbe számára a döntések meghozatala csakis egy liberális rend intézményesített keretein belül, szigorúan szabályozott körülmények között képzelhető el. Ennyiben tehát Lübbe a politikai döntések procedurális elméletének követője, ugyanakkor nem követi a harmadik részben leírt deliberatív demokráciaideált.

A parlamentek azért jönnek létre, hogy döntéseket hozzanak, és nem feltétlenül az legitimálja őket, hogy a döntéshozók ott bölcsebbek, jól informáltabbak vagy morálisan különbek, hanem maga a döntéshozatali eljárás legitimál. „A liberális intézmények politikai döntéseit nem azért követik, mert igazak vagy helyesek, hanem,

31 Odo Marquard híres-hírhedt kompenzáció-elmélete alapján éppen a szellemtudományoknak kellene átvenni azt a feladatot, hogy a modernitásból fakadó veszteségeket orientálással tegyék elviselhetővé. Az, hogy ezzel a szellemtudományok funkciója teljes mértékben vagy egyáltalán kielégítően megragadható-e, az természetesen más lapra tartozik. (Vö. Marquard 2016.)

${ }^{32}$ Vö. Schmitt 1934. 


\section{KÖZELKÉP - Tanulmányok}

mert egy folyamaton keresztül jutottak érvényre." (Lübbét idézi Bolsinger 1998: 487)

Ennek alapelve tehát nem az igazság, hanem a többség, amelyet azonban intézményesíteni kell, és nem általában érvényesül, hanem csakis konkrét döntési helyzetekben. A többséggel természetesen vissza lehet élni, ha azt egy vezér akaratával azonosítják és a tömegek akklamációjává silányítják. Ezekben az esetekben azonban már nem egyszerúen a többségről van szó, hanem arról, hogy a többséget az igazsággal azonosítják..$^{33}$ Lübbe szerint az igazság iránti igény a politikában minden esetben ideológiagyanús, ami végül a totalitás valamilyen elképzeléséhez és követeléséhez vezet. ${ }^{34}$ Ezért jelenti ki, hogy a döntés „a liberalizmus védelmének médiuma a strukturálisan totalitárius érvényességi igényekkel szemben". (Lübbe 1988: 433)

A Ritter-iskola tagjai a döntés szükségességét emelik ki bizonyos helyzetekben, ha például időhiány lép fel, és mégis dönteni kell. Mivel a döntések intézményeken belül születnek, ezért minden körülmények között ennek a keretnek a fenntartását kell szolgálniuk. A döntések továbbá azt a célt szolgálják, hogy a rend támogatóit és ellenfeleit, barátait és ellenségeit beazonosítsák, és közöttük különbséget tegyenek. Az idő hiányára való utalás a legfőbb érv, amit a Ritter-iskola tagjai a diskurzusetika képviselőivel szemben felhoznak. Ezen vita érvei elsősorban abban segíthetnek, hogy a demokratikus döntési folyamatok diskurzuselméleti legitimációjához olyan alternatívával szolgáljanak, amelyek a deszinkronizáció patológiájának fentebb leírt körülményei is között érvényesek.

A modern világban általában bonyolult, vagy akár áttekinthetetlen problémahelyzetekkel szembesülünk, amelyek a döntési helyzetet csak még inkább kiélezik. „Egy döntési szituáció még a legártalmatlanabb helyzetekben is egy kivételes szituáció, amennyiben a szabályok, törvények, vélemények és hagyományok, amelyekhez általában igazodni tudunk, nem segítenek tovább: az ember magára van utalva." (Lübbe 1965: 18)

Hermann Lübbe úgy véli, hogy a normák megalapozhatóak. Elméletben nem zárhatjuk ki, hogy egy diskurzus révén végül egy tényleges és végérvényes konszenzust lehet elérni. Gyakorlati okokból azonban nehéz elképzelni, hogy alapvetően pluralista társadalmakban minden esetben elegendő idő áll rendelkezésre, hogy egy problémát ennek megfelelően végigvitassanak. Ha Rosa diagnózisa helyes, akkor ezek a problémák a sürgető körülmények között csak még inkább kiéleződnek.

${ }^{33}$ Az igazság fogalma ebben a kontextusban megfelel a hidegháború átideologizált szellemiségének, ami azonban ma, a posztfaktuális korban már nem tűnik plauzibilisnek.

${ }^{34}$ Hermann Lübbe elemzésében a modernitás filozófiai hagyományából indul ki. Érvelésében Descartes ideiglenes etikájára (morale par provision), Hobbes politikai alapelvére (auctoritas non veritasfacit legem) és a gyakorlati ész Kantnál megfogalmazott primátusára hivatkozik. Értelmezéseiben az elemzések többnyire egyoldalúak és tendenciózusak, de ezek helyessége mostani gondolatmenetünk szempontjából semmilyen szerepet nem játszik. 


\section{KÖZELKÉP - Tanulmányok}

Ahhoz, hogy hatékonyak maradjunk, az „univerzalizálhatóságra vonatkozó követeléseinket" (Lübbe 1965: 18) a lehető legjobban minimalizálni kell, illetve meg kell fosztani drámai jellegüktől. „A parlamenti vitát a cselekvési kényszer miatt az idő sürgeti. A vita elvileg időben korlátozott és figyelembe kell venni, hogy nem vitázhatunk a végső konszenzusig, hanem a vita szavazással végződik, amelynek során a többség dönt. A hatalommegosztás által jellemzett demokráciában a normák megváltoztatásának kompetenciája a törvényhozás feladata. Ezért a döntése általában a fennálló normák megváltoztatására irányuló határozat." (Marquard 2004: 49)

Mindkét Ritter-tanítvány megkerülhetetlennek és hétköznapinak tekinti a döntést, ugyanakkor megfosztják - a schmitti decizionizmus által sugallt - rendkívüliségétől. Jóllehet a diskurzuselmélet képviselőinek téziseit meglehetősen leegyszerúsítve mutatják be, ebben a kontextusban van egy olyan érv, amely az oldalukra billenti el a vita mérlegét, mert a modern társadalomban az uralommentes kommunikáció révén és a sürgető körülmények között aligha várható el, hogy végső konszenzust érjünk el. Le kell mondanunk a végső indoklásokról az így vagy úgy döntés lehetősége javára, miközben adott esetben a hagyományokra támaszkodunk. Ez a Ritter-iskola liberálkonzervatív krédója, ami semmit sem abszolutizál, de megpróbál a hétköznapi szokásokra és - akár kitalált - hagyományokra visszanyúlni, amelyek a döntéseket lehetővé teszik. Sok esetben tulajdonképpen mindegy, hogy mennyit vitatkozunk, valamikor úgyis eljön a döntési helyzet, amikor az érvek már nem segítenek tovább, és mégis dönteni kell. Ilyen módon, minden döntésben megmarad a voluntarizmus egy pillanata, a tetszőlegességé vagy akár az önkényességé is, amit lehetetlen felszámolni. A voluntarista momentumot tehát lehetetlen kiiktatni, de hatásait az intézmények müködése révén és a döntéshozók commonsense-en alapuló képességei révén lehet ellensúlyozni.

$\mathrm{Az}$, hogy ez a gyakorlatban hogyan múködhet, és hogy a megfelelő stratégiák elegendőek-e ahhoz, hogy a deszinkronizáló patológiákkal szembenézzenek, illetve hogy a demokratikus politikai és társadalmi rend nem kerül-e hátrányba a technikával és a gazdasággal szemben, olyan kérdések, amelyekre ezen a helyen nem adhatunk választ. Mindenesetre egy sor kritikus megfontolást figyelembe kell vennünk. Vajon a gyorsulás a különböző társadalmi dimenzióiban nem járul-e hozzá maga is a commonsense gyengüléséhez? Hogyan határozható meg közelebbről a hagyomány és az innováció viszonya, illetve mértéke? Milyen hagyományokat kell ápolnunk és fenntartanunk, illetve melyekkel kell szakítanunk ${ }^{35}$ És végül, az intézményesítés milyen konkrét formái alkalmasak arra, hogy a voluntarizmus pillanatát figyelembe vegyék és ellensúlyozzák? Különösen akkor éleződik ki ez a kérdés, ha a common-

${ }^{35}$ Egy elméleti és történeti szempontból alapos tanulmány, amely a hagyomány fogalmával és szerepével foglalkozik a morális és politikai diskurzusokban (l. Dittmann 2004). 


\section{KÖZELKÉP - Tanulmányok}

sense-re való hivatkozás a jelen körülményei között elégtelennek és bizonytalannak tűnik.

Meglehetősen sok kérdés marad tehát nyitva az elemzés folytatásához, ezen a helyen azonban meg kell elégednünk a diskurzusetikai modellel szembeni kifogások hangsúlyozásával. Ha a politikaelmélet felhagy azzal, hogy a politikai gyakorlatot egy sikeres diskurzus evaluatív és normatív mércéjével mérje, és ehelyett az eljárásoknak és hagyományoknak enged teret, amelyeknek sikere a gyakorlaton keresztül tűnik ki, akkor talán megszabadulhatunk a legitimációs nyomás egy bizonyos részétől, ami a politika mai döntési rendszerét elöregedettnek és korszerütlennek mutatja.

\section{Eredmények és nyitott kérdések}

Tézisünk úgy szólt, hogy a Ritter-iskola megfontolásainak alkalmazhatóvá tétele érdekében, azokra a kihívásokra kell konstruktív módon reflektálnunk, amelyek a demokrácia és elmélete, illetve a társadalmi gyorsulás összefüggéséből adódnak. Különösen sokat ígérő pontnak ígérkezik, hogy a Ritter-iskola gondolatai nyomán egy explicit módon előálló, illetve előállított helyzetről beszélünk, amikor is a döntés sürgőssé és sürgetővé válik. A döntéseket nem csak úgy foghatjuk fel, mint amiknek szükségszerűen ellentétes körülmények között kell történnie, hanem olyan lehetőségekként is feltűnhetnek, amelyek az irányvesztés és tehetetlenség kollektív érzéséből is kiutat képesek találni, amelyeket a jelenzsugorodásához kapcsolódó különböző jelenségek okoznak. A politikai döntések teszik a cselekvési lehetőségek egyre növekvő mennyiségét kézben tarthatóvá és alakíthatóvá. A Ritter-iskola megfontolásai meglehetősen izgalmasak, és arra ösztönöznek, hogy a demokrácia politikai eljárásait úgy szervezzük meg, hogy a rendszeres szavazások szükségesek legyenek, és a politikai döntés segítségével, amelyet a többségi elv szabályoz, a kollektív tehetetlenséget kollektív cselekvési lehetőségbe alakíthassuk át. Az egyszer már meghozott döntések rendszeres korrekciójának és újrahangolásának lehetővé tétele új döntési helyzetekben segít a minden döntésben jelen levő voluntarista jelleget enyhíteni, és így az idő sürgető körülményei között is megfosztani a döntést drámai jellegétől.

Kétségtelen, hogy egy ilyen eljárás a politikai szereplőktől magas szintű demokratikus kompetenciát és ennek megfelelő politikai erényeket kíván. A politikai konfliktusokat nem lehet egy mindent eldöntő politikai fordulatot hozó választási harcként inszcenálni; a demokratikus eljárást olyannak kell mutatni, mint amelynek során hibázhatunk, de azt egyben korrigálhatjuk is. Ezekkel a megfontolásokkal jelezzük, hogy a demokráciaelmélet hogyan reagálhat a társadalmi gyorsulás körülményeire. Nem csak a racionalitás kritériumától, mint a politikai döntések általános igazolhatóságának követelményétől kell eltávolodnia, hanem ezzel együtt új kritériumokat is meg kell alapoznia. Ehhez tartozik egyrészt a politikai döntéshelyzetek rendszeres megteremtése és a politikai decizionizmussal szembeni intézményesítő nyitás. 


\section{KÖZELKÉP - Tanulmányok}

Másrészt az itt felvázolt megfontolások a demokratikus társadalmak politikai kultúrájával szemben állítanak fel bizonyos követelményeket. A demokrácia sikerének nem csak a demokratikus részvételi- és akaratképzési folyamat a feltétele, hanem a politikai szocializáció, amely a polgároknak beláthatóvá teszi, hogy mindannyian képesek vagyunk tévedni, és törékeny politikai képződményekben élünk, amelyekben a döntés felelőssége minden érintetten múlik. Éppenséggel a közösség nagy politikai döntései és az egyénhétköznapi élethelyzeti döntései közötti hiátust kell leépíteni, mivel ezek között nincs lényegi strukturális különbség.

Ennek a tanulmánynak elsődlegesen az volt a célja, hogy felhívja a figyelmet arra, hogy a mai társadalmi gyorsulásnak milyen következménye van a politikai döntések elméletére, illetve, hogy megmutassa, hogy a mai politikaelméleti vitákban meszszemenően figyelmen kívül hagyott elméleti iskola - azaz a Ritter-iskola - milyen továbbgondolásra ösztönző ötleteket nyújt a kérdéssel való foglalkozáshoz. Annál többre ez a tanulmány nem vállalkozhat, mint hogy benne a kérdés iránti érzékenységet kifejezzük, strukturáljuk és perspektívába helyezzük. További idő- és döntéselméleti kiegészítésekre és újragondolásokra is szükség van ahhoz, hogy megvizsgáljuk, milyen körülmények között alakul ki az a helyzet, amikor az idő sürget, és mi van akkor, ha a társadalmat megosztó, vagy annak részéről elutasítandó döntésekről van szó. A tanulmány a döntéselmélet szempontjából normatív és deskriptív kiegészítéseket és módosításokat tesz. Deskriptíve az vizsgálja, hogy mely esetekben áll elő a döntéskényszer, hogyan jelenítik meg, és milyen esetekben vezet nem elfogadott, a társadalmat megosztó döntésekhez. Normatív szempontból azt vizsgálja, hogy mennyire kell a politikai döntések kritériumait pontosítani és kiterjeszteni ahhoz, hogy a demokratikus gyakorlatot egy igényes normatív kritika tárgyává tehessük, amely döntéseket kényszerít ki és nem engedi, hogy egy általánosító racionalitás követelményébe túlzottan belegabalyodjunk.

\section{Irodalom}

Besson, S. - Martí, J. L. (2006): „Introduction”. In: Besson, S. - Martí, J. L. (Hrsg.): Deliberative Democracy and Its Discontents. London, New York, XIII-XXXI.

Bolsinger, E. (1998): Was ist Dezisionismus? Rekonstruktion eines autonomen Typspolitischer Theorie. In: Politische Vierteljahresschrift Jahrgang 39. Heft 3. 471-502.

Crouch, C. (2011): Das befremdliche Überleben des Neoliberalismus. Berlin, Suhrkamp.

Crouch, C. (2015): Die bezifferte Welt. Wie die Logik der Finanzmärktedas Wissen bedroht. Berlin, Suhrkamp. 


\section{KÖZELKÉP - Tanulmányok}

Dittmann, K. (2004): Tradition und Verfahren. Philosophische Untersuchungen zum Zusammenhang von kultureller Überlieferung und kommunikativer Moralität. Norderstedt, Books on Demand GmbH.

Eberlein, B. - Grande, E. (2014): „Entscheidungsfindung und Konfliktlösung“. In: Klaus, S. - Nils, B. (Hrsg.): Lehrbuch der Politikfeldanalyse. München, S. 151-176.

Hartmann, D. (1996): „Kulturalistische Handlungstheorie“. In: Dirk, H. - Peter, J. (Hrsg.): Methodischer Kulturalismus. Zwischen Naturalismus und Postmoderne. Frankfurt a.M., Suhrkamp, 70-114.

Koselleck, R. (2003 [1979]): Elmúlt jövő. A történeti idók szemantikája Elmúlt jövő. Budapest, Atlantisz Kiadó.

Luhmann, N. (2000): Die Politik der Gesellschaft. Frankfurt a.M., Suhrkamp.

Lübbe, H. (1965): Zur Theorie der Entscheidung. In: Lübbe, H.: Theorie und Entscheidung. Freiburg 1971, 7-31.

Lübbe, H. (1979): Erfahrungsverluste und Kompensationen. Zum philosophischen Problem der Erfahrungin der gegenwärtigen Welt. In: Giessener UniversitätsblätterJ ahrgang XII, Heft 2, Dezember 42-53.

Lübbe, H. (1980): Philosophie nach der Aufklärung. Von der Notwendigkeit pragmatischer Vernunft. Düsseldorf / Wien.

Lübbe, H. (1988): Carl Schmitt liberalrezipiert. In: Quaritsch Helmut (Hrsg.): Complexio Oppositorum. Über Carl Schmitt, Berlin, Duncker \& Humblot, 427-440.

Lübbe, H. (2000): Gegenwartsschrumpfung und zivilisatorische Selbsthistorisierung. In: Frithjof Hager - Werner Schenkel (Hg.): Schrumpfungen. Chancen für ein anderes Wachstum. Ein Diskurs der Natur- und Sozialwissenschaften. Berlin/ Heidelberg, 11-20.

Lübbe, H. (1998): „Gegenwartsschrumpfung“. In: Klaus Backhaus - Holger Bonus (Hrsg.): Die Beschleunigungsfalle oder der Triumph der Schildkröte. Stuttgart, Schäffer-Poeschel, 129-164.

Lübbe, H. (2003): „Gegenwartssschrumpfung. Ein neuer Begriffweckt Interesse.” In: Im Zug der Zeit. Verkürzter Aufenthalt in der Gegenwart. 3. Auflage. Berlin/Heidelberg, Springer, 399-404.

Marquard, O. (2004): „Das Über-Wir. Bemerkungen zur Diskursethik”. In: Individuum und Gewaltenteilung. Philosophische Studien. Stuttgart, Reclam, 38-67.

Marquard, O. (2016): „Über die Unvermeidlichkeit der Geisteswissenschaften.” In: Panteos, Athena - Tim Rojek (Hrsg.): Texte zur Theorie der Geisteswissenschaften. Stuttgart, Reclam, 253-266.

Müller-Salo, J. - Westphal, M. (2018): „Zeitpolitik. Zur zeitsoziologischen Herausforderung der politischen Philosophie." In: Zeitschrift für Praktische Philosophie. 


\section{KÖZELKÉP - Tanulmányok}

Nolte, P. (2012): Was ist Demokratie? Geschichte und Gegenwart. München.

Raphael, L. (1996): „Die Verwissenschaftlichung des Sozialenalsmethodische und konzeptuelle Herausforderung für eine Sozialgeschichte des 20. Jahrhunderts." In: Geschichte und Gesellschaft 22 (2), S. 165-193.

Rosa, H. (2005): Beschleunigung. Die Veränderung der Zeitstrukturen in der Moderne. Frankfurt a.M., Shurkamp.

Rosa, H. (2013): Beschleunigung und Entfremdung. Entwurf einer Kritischen Theorie spätmoderner Zeitlichkeit. Berlin, Suhrkamp.

Rüb, F. W. (2002): Hybride Regime - politikwissenschaftliches Chamäleon oder neuer Regimetypus? Begriffliche und konzeptionelle Überlegungen zum neuen Pessimismusin der Transitologie. In: Petra, B. - Aurel, C. - Rüb, F. W. (Hrsg.): Zwischen Demokratie und Diktatur. Wiesbaden, S. 93-118.

Schimank, U. (2005): Die Entscheidungsgesellschaft. Komplexität und Rationalität der Moderne. Wiesbaden.

Schweda, M. (2015): Joachim Ritter und die Ritter-Schule. Hamburg, Junius Verlag $\mathrm{GmbH}$.

Stollberg-Rilinger, B. (2016): Cultures of Decision-Making. London, Springer.

Wille, M. (2012): Transzendentaler Antirealismus. Grundlagen einer Erkenntnistheorie ohne Wissens transzendenz. Berlin/Boston. 